\title{
Horizontal Gene Transfer from Genus Agrobacterium to the Plant Linaria in Nature
}

\author{
Tatiana V. Matveeva,, ${ }^{1}$ Denis I. Bogomaz,, ${ }^{1}$ Olga A. Pavlova,, ${ }^{1}$ Eugene W. Nester, ${ }^{2}$ and Ludmila A. Lutova ${ }^{1}$ \\ ${ }^{1}$ Department of Genetics, St. Petersburg State University, 7/9, Universitetskaya emb., St. Petersburg, 199034, Russia; \\ ${ }^{2}$ Department of Microbiology, University of Washington, Box 357735, Seattle 98195, U.S.A.
}

Submitted 8 July 2012. Accepted 12 August 2012.

Genes can be transferred horizontally between prokaryotes and eukaryotes in nature. The best-studied examples occur between Agrobacterium rhizogenes and certain Nicotiana spp. To investigate possible additional cases of horizontal gene transfer in nature between Agrobacterium and plants, a real-time polymerase chain reaction-based approach was employed to screen 127 plant species, belonging to 38 families of Dicotyledones, for the presence of oncogenes homologous to the transfer DNA fragments (T-DNA) from both $A$. tumefaciens and $A$. rhizogenes. Among all of the analyzed plant species, we found that only Linaria vulgaris contained sequences homologous to the T-DNA of $A$. rhizogenes. All screened $L$. vulgaris plants from various parts of Russia contained the same homologous sequences, including rolB, rolC, ORF13, ORF14, and mis genes. The same opine gene is found in the species of Nicotiana which contain genes of $A$. rhizogenes. In $L$. vulgaris, there are two copies of T-DNA organized as a single tandem imperfect direct repeat. The plant DNA sequence of the site of integration shows similarity to a retrotransposon. This site is most likely silent, suggesting that the T-DNA is not expressed. Attempts to demonstrate expression of the T-DNA genes were negative. Our study indicates that the frequency of gene transfer and fixation in the germline from Agrobacterium to plant hosts is rare in the natural environment.

Horizontal gene transfer (HGT) is a subject of major interest to a wide variety of disciplines, ranging from antibiotic resistance to genetically modified organisms. HGT occurs extensively in prokaryotic organisms, and its ecological and evolutionary impact is well documented (Koonin et al. 2001). Comparative analyses of bacterial, archaeal, and eukaryotic genomes indicate that a significant fraction of the genes in prokaryotic genomes is susceptible to horizontal transfer. HGT is a creative force, driving much of the similarities and differences between prokaryotic microbes. The fixation and longterm persistence of horizontally transferred genes suggest that they confer selective advantages such as antibiotic resistance, virulence, or nitrogen fixation to the recipient organism

\section{Corresponding author: T. Matveeva; E-mail: radishlet@gmail.com}

Sequence data from this article have been deposited to GenBank under the accession number EU735069. These new sequences were compared with sequences from GenBank X03433, K03313, AP002086, AB071334.1, AB07335.1, AJ851042.1, AJ851070.1, and AJ851066.1.

*The $\boldsymbol{e}$-Xtra logo stands for "electronic extra" and indicates that four supplementary figures and three supplementary tables are published online. Also, Figures 1 and 6 appear in color online.
(Gogarten et al. 2002; Koonin et al. 2001; Richardson and Palmer 2007). Evidence indicates that HGT between eukaryotes is a rare event. HGT in higher plants involves primarily DNA of mitochondria or chloroplasts (Dong et al 1998; Richardson and Palmer 2007). The horizontal transfer of nuclear genes between plant species is only vaguely described. Virusmediated transfer of the gene encoding the cytosolic enzyme phosphoglucose isomerase was hypothesized to have occurred between Festuca ovina to distant relatives in the genus Poa (Ghatnekar et al. 2006; Vallenback et al. 2008, 2010).

HGT between prokaryotes and eukaryotes also is not well characterized. Only a few cases of eukaryote to prokaryote transfers have been reported (Jenkins et al. 2002; Rogers et al. 2007; Schlieper et al. 2005). The rare examples of transfer of genes from bacteria to the nuclei of multicellular eukaryotes involve the transfer to fungi and animals (Acuna et al. 2012; Garcia-Vallve et al. 2000; Kondo et al. 2002; Richards et al. 2006; Rosewich and Kistler 2000; Screen and St. Leger 2000; Veronico et al. 2001). HGT from prokaryotes to plants has been limited to Agrobacterium rhizogenes and Nicotiana spp. (Intrieri and Buiatti 2001; White et al. 1983).

A. tumefaciens and A. rhizogenes transfer DNA fragments (T-DNA) from a large tumor-inducing (Ti) plasmid or rootinducing (Ri) plasmid, respectively, to their hosts (Otten et al. 1992; Tzfira and Citovsky 2006; Vain 2007; Veena et al. 2003; White et al. 1982). The expression of genes encoded in the TDNA is responsible for the neoplastic diseases of crown gall and hairy root in plants. The tumors represent transgenic tissues on a nontransgenic plant. However, in the natural environment of the plant, the fixation of the T-DNA insertion in the plant genome and its subsequent transfer via sexual reproduction (i.e., a vertical transfer) has been shown for only one plant genus, Nicotiana. In this case, the donor of the T-DNA was identified as a strain of $A$. rhizogenes that synthesized the opine mikimopine, and this represents the lone example of HGT from Agrobacterium to a plant that has been fixed (Furner et al. 1986; Suzuki et al. 2002; White et al. 1983). Analyses of the T-DNA of Nicotiana spp. led Suzuki and associates (2002) to hypothesize that T-DNA might have been transferred to Nicotiana spp. by several independent events. Regardless of these events, one or more ancient transfers occurred between A. rhizogenes and an ancient progenitor of modern tobacco. These T-DNA sequences were named cellular T-DNA (cTDNA). Significantly, all of the cT-DNA genes are expressed in a tissue-specific manner and their expression changes during plant ontogenesis, raising the possibility that genes of bacterial origin introduced during evolution may have or have had at some time a selective value for extant species (Aoki et al. 1994; Ichikawa et al. 1990; Intrieri and Buiatti 2001; Meyer et al. 1995; Nagata et al. 1995). 
Given the documented occurrence of cT-DNA, we hypothesized that other plant species, in addition to species of Nicotiana, would have been transformed and contain at least remnants of T-DNA. Previous studies that attempted to determine how widespread fixed HGT was from Agrobacterium to plants involved conventional techniques, such as Southern hybridization of T-DNA probes with DNA from untransformed plants, and did not include sequencing experiments. They did not give a final reliable answer of whether there is T-DNA in the analyzed species (Matveeva et al. 2003; Spano et al. 1982). In this study, we aimed to establish whether fixed T-DNA exists in other plants outside the Nicotiana genus, in order to assess the evolutionary relevance of natural T-DNA transfer. We undertook an approach to rapidly screen a large number of plant species for T-DNA from both A. tumefaciens and A. rhizogenes in their genomes. We applied a modification of real-time polymerase chain reaction (PCR) that combines the positive features of PCR and Southern hybridization in a single reaction (Blair et al. 2002; Livak et al. 1995; Matveeva et al. 2006; Salvi et al. 2008). Further, we limited our search to dicotyledonous plants growing in the temperate zone (warm summer, mild winter, and sufficient rainfall) due to the ubiquitous occurrence of Agrobacterium in soils under these conditions (Otten et al. 2007).

\section{RESULTS}

\section{Screening of plant species}

for the presence of Agrobacterium oncogenes.

A modified TaqMan real-time PCR protocol was used to detect sequences homologous to the T-DNA genes from Agrobacterium (discussed below). We screened each of the plants for sequences homologous to two different T-DNAs. The first set consisted of sequences homologous to A. rhizogenes oncogenes (rolB, rolC, open reading frame $[O R F] 13$, and $O R F 14$ ), and the second set included sequences homologous to $A$. tumefaciens oncogenes (tms 1 and $t m r$, from strains pTiC58, pTiSAKURA, pTiBo542, pTiCG474, pTiT37, PO22, and pTi15955). These sequences were chosen because they are particularly conserved between strains.

For the first screen, Nicotiana glauca genomic DNA, in which T-DNA from $A$. rhizogenes is known to be present, was used as a positive control. (White et al. 1983). Because T-DNA genes from $A$. tumefaciens have not been reported in any plant genome, we used $A$. tumefaciens DNA as the positive control for the second set of experiments. No fluorescent signal was detected in PCR reactions without template DNA.

Plant samples were collected from several different ecosystems in the St. Petersburg region of Russia. They represented 127 dicotyledonous plant species belonging to 38 different families (Supplementary Table S1). Plant samples from 126 species did not exhibit detectable fluorescent signals for the TDNA genes from either A. rhizogenes or A. tumefaciens. However, DNA extracted from three plants of Linaria vulgaris, each one collected from different districts of the St. Petersburg region of Russia, was scored as positive. L. vulgaris (toadflax) (Fig. 1) is a species native to most parts of Europe and Northern Asia, and is now common in North America following cultivation and escape. The plant is a perennial with short spreading roots, erect to decumbent stems 15 to $90 \mathrm{~cm}$ high, with fine, threadlike, glaucous blue-green leaves (Gubanov et al. 2003, 2004).

DNA fragments (approximately $500 \mathrm{bp}$ in size) homologous to $\mathrm{rolB}, \mathrm{rolC}, \mathrm{ORF13}$, and ORF14 genes of A. rhizogenes were amplified using genomic DNA extracted from a single $L$. vulgaris plant from the St. Petersburg region (Fig. 2). The sizes of the amplified fragments matched the size of the fragments cor- responding to the Agrobacterium genes. PCR fragments homologous to rolB, rolC, ORF13, and ORF14 were cloned and sequenced. The DNA sequences shared more than $85 \%$ homology to the oncogenes of $A$. rhizogenes A4. The T-DNA sequences in Linaria spp. were named $\mathrm{Lv}$ rolB, $\mathrm{Lv}$ rolC, $\mathrm{Lv}$ ORF13, and Lv ORF14. BLAST analyses against sequences presented in the databases showed that the highest similarity (93\%) was observed between $\mathrm{Lv}$ rolC and rolC from the A4 strain of $A$. rhizogenes (accession number X03433) (Supplementary Fig. S1A). Lv ORF14 had the lowest similarity to the corresponding Agrobacterium oncogene (85\%) (accession number K03313). In contrast, no amplification was observed with primers from the $t m s 1$ and $t m r$ genes of $A$. tumefaciens (data not shown).

Additional L. vulgaris samples were collected in the European part of Russia from north to south spanning a distance of $700 \mathrm{~km}$ (in Moscow, Voronezh, and Krasnodar regions) and in the Asian part of Russia (in the Novosibirsk, Tumen, and Chelyabinsk regions) spanning a distance of 2,000 km. Two to three plants were screened from each of these regions. The distance between the most western and the most eastern points was approximately $4,000 \mathrm{~km}$. All of the samples contained DNA sequences homologous to $\operatorname{rolB}$, rolC, ORF13, and ORF 14 genes.

To eliminate the possibility that the results were a consequence of Agrobacterium contamination, PCR was carried out with primers specific for three conserved $A$. rhizogenes vir genes (virB2, virD2, and virG). These vir genes are part of the Ti and Ri plasmids from A. tumefaciens and A. rhizogenes, respectively, and they are highly conserved (Supplementary Fig. S2) but are not transferred to plants. Thus, their presence in DNA samples would indicate that the DNA was isolated from cells of Agrobacterium. A band of the size expected for each

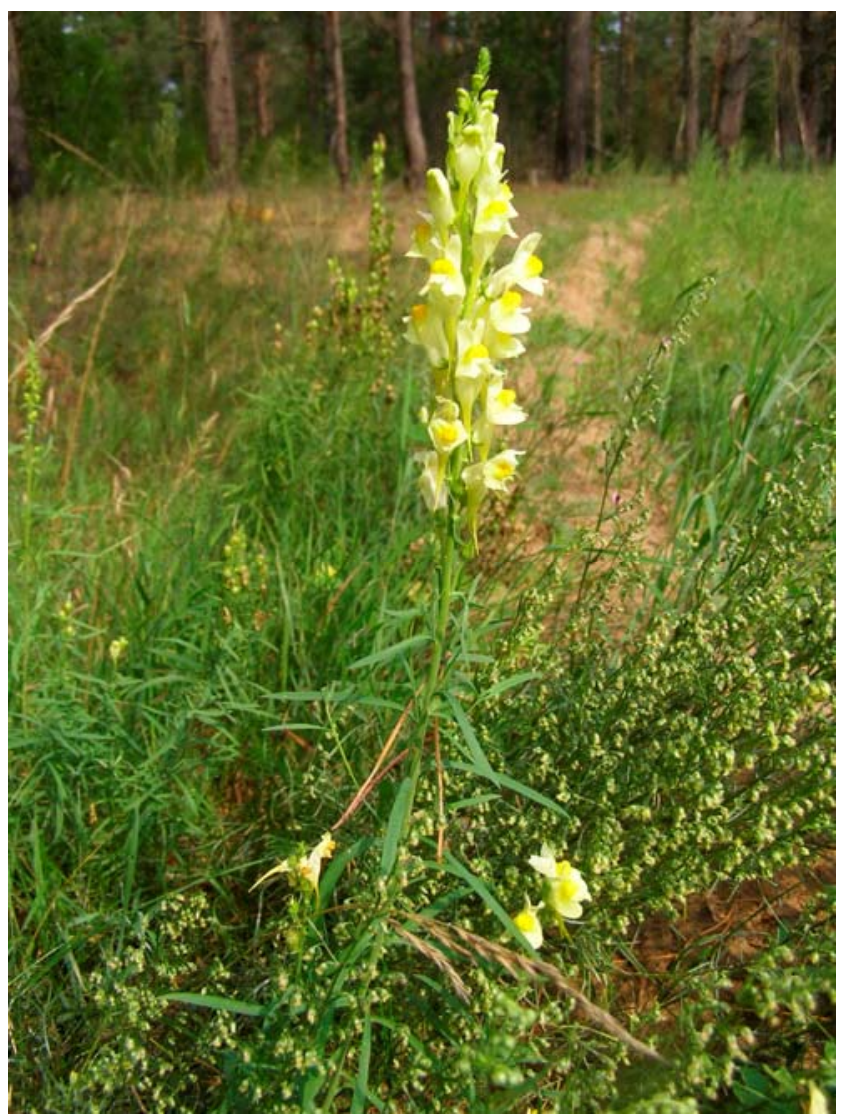

Fig. 1. Linaria vulgaris. 
of the three genes was detected only in the control DNA extracted from $A$. rhizogenes, not in the DNA isolated from $L$. vulgaris (Fig. 3). These results indicate that the L. vulgaris DNA was not contaminated with $A$. rhizogenes DNA.

\section{L. vulgaris cT-DNA sequences.}

To further define the strain of A. rhizogenes that infected L. vulgaris, we sought to identify any opine synthase genes in the Lv T-DNA sequence. PCR with primers to four different opine synthase genes-ags, mis, nos, and cuc-was performed. Amplification was successful only for the mis gene, which encodes the opine synthase gene for mikimopine. DNA sequencing of the PCR product showed that the percentage of identity to the corresponding gene from pRi 1724 (accession number AP002086) and genes $N g$ misL and $N g$ misR from the
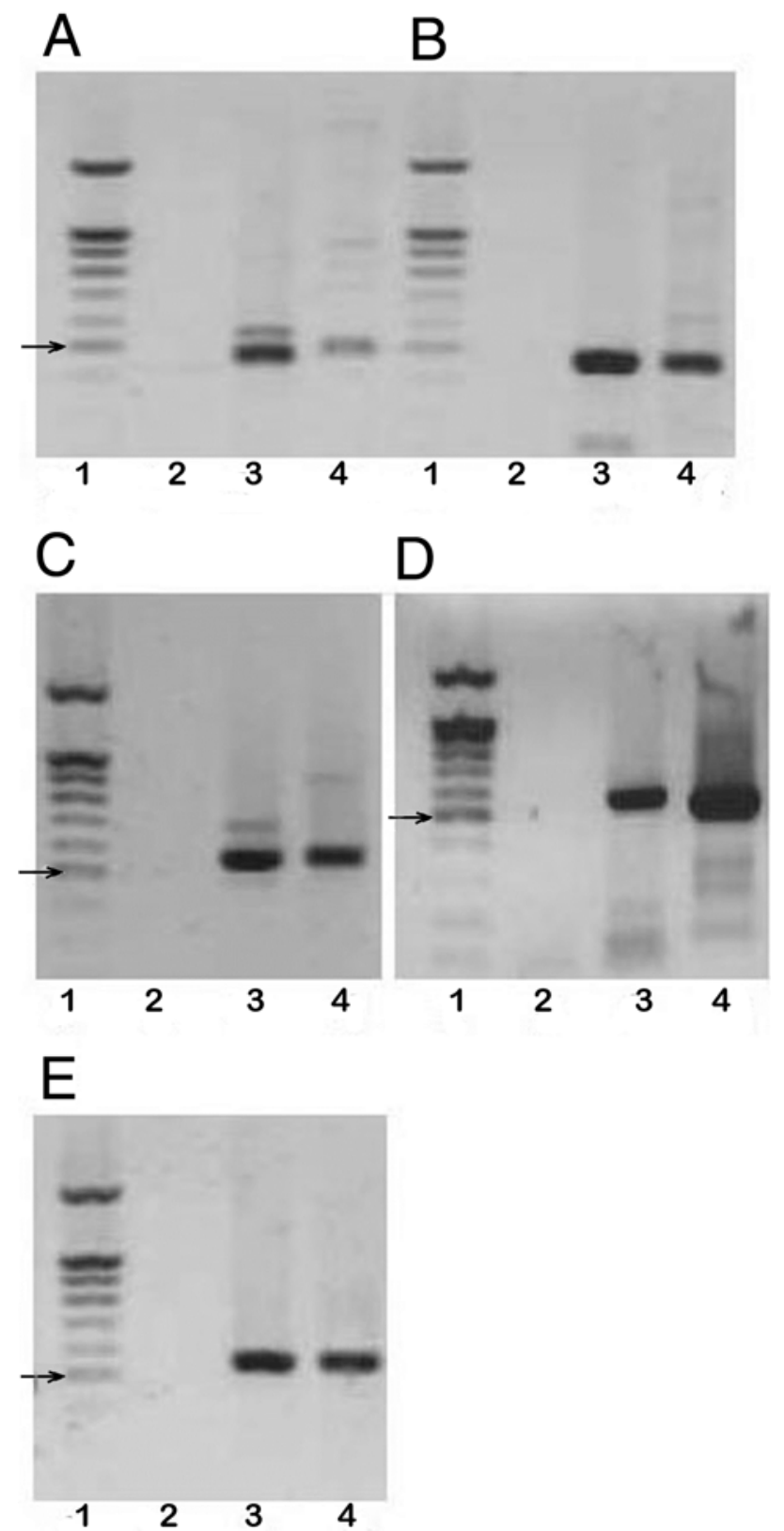

Fig. 2. Polymerase chain reaction analysis of Linaria vulgaris plants with primers to oncogenes $\mathbf{A}$ and $\mathbf{B}, \operatorname{rolB}$ (overlapping fragments); $\mathbf{C}, \operatorname{rolC} ; \mathbf{D}$, ORF13; and E, ORF14 from Agrobacterium rhizogenes. Lane 1, molecular weight marker (100-bp + 1.5-kb ladder; Sibenzyme); arrow shows 500-bp fragment. Lane 2, negative control; lane 3, strain 8196 of A. rhizogenes (positive control); and lane 4, L. vulgaris. left and right T-DNA arms of $N$. glauca (accession numbers $\mathrm{AB} 071334.1$ and $\mathrm{AB} 071335.1$ ) was 89, 88, and 89\%, respectively (Supplementary Fig. S3).

Sequencing of the intergenic fragments of Lv T-DNA revealed that the percentage of identity corresponding to the noncoding spacers of Agrobacterium sp. strain A4 T-DNA is lower than that for the coding regions. The highest value $(86 \%)$ was for the rolC-ORF13 spacer. On the other hand, this value was less than $79 \%$ for the rolB-rolC spacer. Among the 313 nucleotides of the ORF14-mis spacer, only 68 show similarity to the corresponding sequence of pRi1724 and their percentage of identity is $78 \%$. These data suggest that T-DNA genes in L. vulgaris mutated more slowly than the intergenic spacers. The most conserved sequence among the oncogenelike sequences in L. vulgaris is rolC (Supplementary Fig. S4).

To determine the full extent of the cT-DNA incorporated into Linaria spp., a chromosome walking approach (discussed below) was used to sequence the upstream fragment of the Lv T-DNA. This sequencing revealed that sequences homologous to ORF2, ORF3, ORF8, and rolA are present. Further chromosome walking revealed that other sequences homologous to the mis gene are connected to the $O R F 2$ fragment. We conclude that there are two copies of T-DNA in the L. vulgaris genome, which are organized as direct repeats. Sequencing analysis of the left T-DNA copy showed that it contains the same genes as the right copy and additional sequences homologous to ORF2 and part of the agrocinopine synthase (acs) gene.

In order to more fully define the structure of the two copies of the Lv T-DNA, PCR using the LONG PCR enzyme Mix (Fermentas, Vilnius, Lithuania) was carried out. Sequencing of the left and right copies of the T-DNA confirmed that both copies contain sequences homologous to $O R F 2, O R F 3, O R F 8$, rolA, rolB, rolC, ORF13, ORF14, and the mis gene. A schematic diagram of the L. vulgaris T-DNA organization based on these sequencing data is shown in Figure 4. Large PCR fragments, obtained with primers $\mathrm{LF}+\mathrm{LR}$ and $\mathrm{RF}+\mathrm{RR}$, correspond to

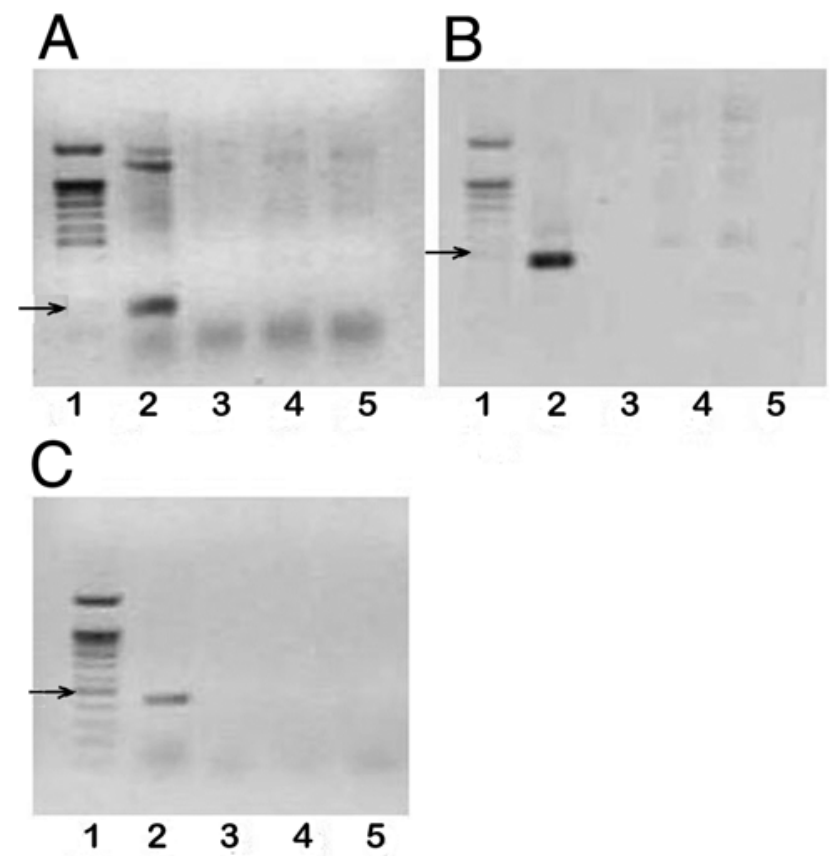

Fig. 3. Polymerase chain reaction analysis of independent Linaria vulgaris plants with primers to some vir genes from Agrobacterium: A, virB2; B, virD2; and $\mathbf{C}$, virG. Lane 1, molecular weight marker (100-bp + 1.5-kb ladder; Sibenzyme); arrows show 200-bp (A) and 500-bp (B and C) fragments. Lane 2, strain 8196 of A. rhizogenes (positive control); lanes 3 to 5, independent $L$. vulgaris plants. 
the left and right copies of the Lv-TDNA. The positions of these primers are shown as black arrows in Figure 4A. The PCR primers annealing to $O R F 2$ and mis were used to amplify the DNA sequence connecting the two Lv T-DNA copies (Fig. $4 \mathrm{~A}$ and $\mathrm{B}$, gray arrows). The PCR fragments (amplified on DNA of three independent L. vulgaris plants), including part of $O R F 2$ from the right T-DNA copy and part of the mis gene and the distal part from the left T-DNA copy (Fig. 4C) indicate the same structure of the repeats in all three studied plants. Comparing the left and the right copies of the Lv T-DNA revealed that their sequences differ in point mutations distributed throughout the sequences. In addition, deletions were found in the spacers between ORF8-rolA (52 bp), rolC-ORF13 (219 bp), and ORF13-ORF14 (123 bp) in the right arm of the T-DNA. The similarities between Lv cT-DNA sequences and the corresponding Agrobacterium T-DNA genes are shown in Table 1. The sequences are deposited in GenBank under accession number EU735069.2.

In order to determine whether there is more than one copy of the imperfect repeats, we performed a copy number assay by digital PCR (Sykes et al. 1992). The single-copy gene for glyceraldehyde 3-phosphate dehydrogenase ( $g a p d h)$ was used as a reference. Analyses of amplification of the gapdh gene fragment and the $5^{\prime}$ fragment of ORF2 (unique for the left copy of the Lv T-DNA) was done in 64 independent tubes. For gapdh, we observed amplification in 14 of 64 tubes; for $O R F 2$, we observed amplification in 15 of 64 tubes. This corresponds to 15 to 16 molecules of the gapdh fragment and 16 to 17 molecules of the ORF2 fragment. These data show equal amounts of the gapdh and 5' ORF2 (unique to the left copy) fragments in the analyzed DNA sample. This suggests that there is one copy of the imperfect repeats of T-DNA in the L. vulgaris genome.
Integration site.

We next analyzed the flanking regions of the Lv T-DNA to determine the integration site of the T-DNA in the L. vulgaris genome. The right flanking region of the Lv T-DNA was initially analyzed in a single plant by real-time thermal asymmetrical interlaced (TAIL)-PCR with primers and probes to the mis gene. This flanking region contains a part of the mis gene, right T-DNA border, and 80 nucleotides of the flanking plant DNA. The fragment of the plant DNA has $78 \%$ similarity to the centromere region of chromosome 4 (accession number

Table 1. Percentage of identity of Linaria oncogenes to oncogenes of Agrobacterium rhizogenes strains

\begin{tabular}{|c|c|c|c|c|}
\hline \multirow[b]{2}{*}{ Gene } & \multicolumn{4}{|c|}{ Identity to oncogenes of $A$. rhizogenes strains (\% } \\
\hline & A4 & K599 & 2659 & 1724 \\
\hline$O R F 2 L$ & 71 & 81 & 80 & 81 \\
\hline$O R F 3 L$ & 77 & 81 & 81 & 81 \\
\hline$O R F 8 L$ & 89 & 76 & 76 & 76 \\
\hline rolAL & 80 & 66 & 66 & 66 \\
\hline rolBL & 91 & 80 & 80 & 80 \\
\hline rolCL & 91 & 76 & 76 & 77 \\
\hline ORF $13 L$ & 84 & 86 & 86 & 85 \\
\hline ORF $14 L$ & 86 & 80 & 80 & 81 \\
\hline misL & $\ldots$ & $\ldots$ & $\ldots$ & 88 \\
\hline$O R F 2 R$ & 75 & 83 & 82 & 83 \\
\hline$O R F 3 R$ & 78 & 80 & 80 & 80 \\
\hline ORF $8 R$ & 94 & 86 & 86 & 91 \\
\hline rolAR & 81 & 67 & 67 & 67 \\
\hline rolBR & 90 & 82 & 82 & 77 \\
\hline rolCR & 93 & 77 & 77 & 78 \\
\hline ORF 13R & 86 & 88 & 88 & 87 \\
\hline ORF $14 R$ & 85 & 79 & 79 & 80 \\
\hline misR & $\ldots$ & $\ldots$ & $\ldots$ & 89 \\
\hline
\end{tabular}

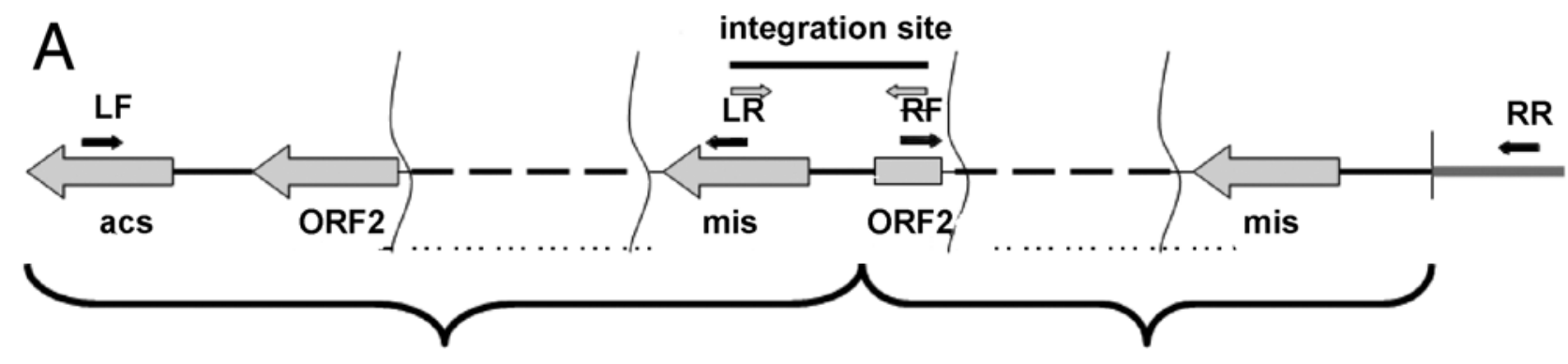

left copy

right copy

Plant DNA

B

\section{PCR fragment, illustrating connecting sequence}
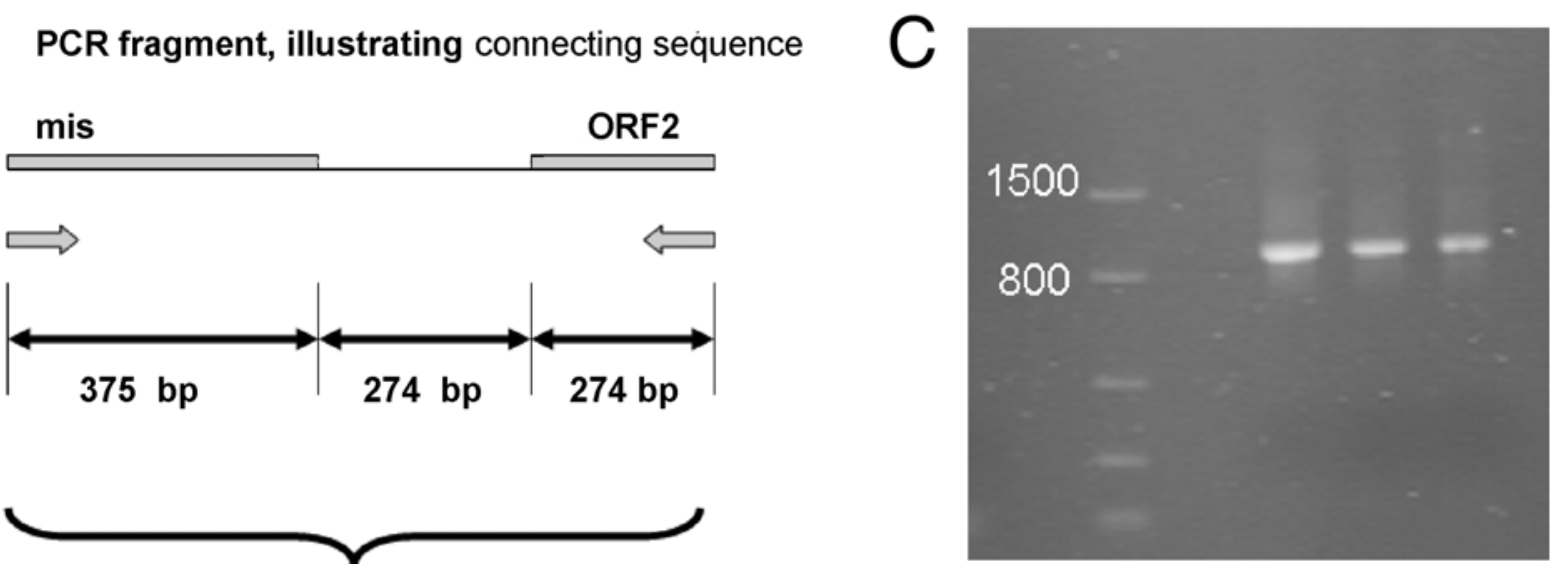

$923 \mathrm{bp}$

Fig. 4. Schematic diagram of cellular transfer DNA fragments (cT-DNA) in Linaria vulgaris. A, Schematic diagram of the direct repeat of T-DNA in L. vulgaris. B, Schematic diagram of the polymerase chain reaction (PCR) fragment connecting the two T-DNA copies. C, Photo of PCR fragments from three independent reactions on DNA of $L$. vulgaris plants. 
AB073162) of Arabidopsis thaliana. The plant DNA (approximately 62 nucleotides) has $77 \%$ similarity to the Ty3/gypsylike retrotransposon of Vicia faba (accession number AJ851042.1) and the DNA (approximately 40 nucleotides) also has more than $85 \%$ similarity to the Ty3/gypsy-like retrotransposon of $V$. sativa (accession numbers AJ851070.1 and AJ851066.1).

In order to determine whether the integration site was the same in different $L$. vulgaris plants, PCR was performed using the primer mis4 and a primer that was specific to the Ty3/gypsy-like retrotransposon sequence. Genomic DNA samples from different $L$. vulgaris plants that were geographically separated (collected in Leningrad, Krasnodar, Voronezh, Chelyabinsk, and the Novosibirsk regions) were used as templates. PCR amplification was observed in all cases, albeit the sizes of the products were different. Two variants of PCR products were isolated and sequenced (Fig. 5). The first type of sequence was identical to the integration site sequenced described above $(78 \%$ similar to a fragment of accession number AB073162). The second type of PCR product showed the same flanking fragment of the plant DNA but its Lv T-DNA fragment contained
150 additional nucleotides, which are located 13 nucleotides downstream of the gene mis and show similarity to a fragment of pRi1724 (AP002086.1), positions 26,137 to 26,287.

Expression of the T-DNA genes.

Because the similarity between Agrobacterium rhizogenes T-DNA genes and the corresponding $L$. vulgaris cT-DNA sequences is higher than that between noncoding sequences, it seemed possible that some of these genes are expressed in planta. The analysis of the sequence for both copies of $\mathrm{Lv}$ rolC showed that they contain intact ORFs. Fragments corresponding to the coding sequences of genes Lv rolB, Lv ORF13, Lv $O R F 14$, and mis contain several stop codons or frameshift mutations that compromise the ORF. RolC amino acid sequences were compared with their corresponding sequences in the A4 strain. The left copy has $88 \%$ identity to the Agrobacterium protein and the right copy has $92 \%$ identity.

Expression analysis of each of these genes using reversetranscription (RT) real-time PCR was carried out in leaves, internodes, and roots of 1-month-old, aseptically grown plants in vitro, as well as in calli, induced on leaves by treatment with
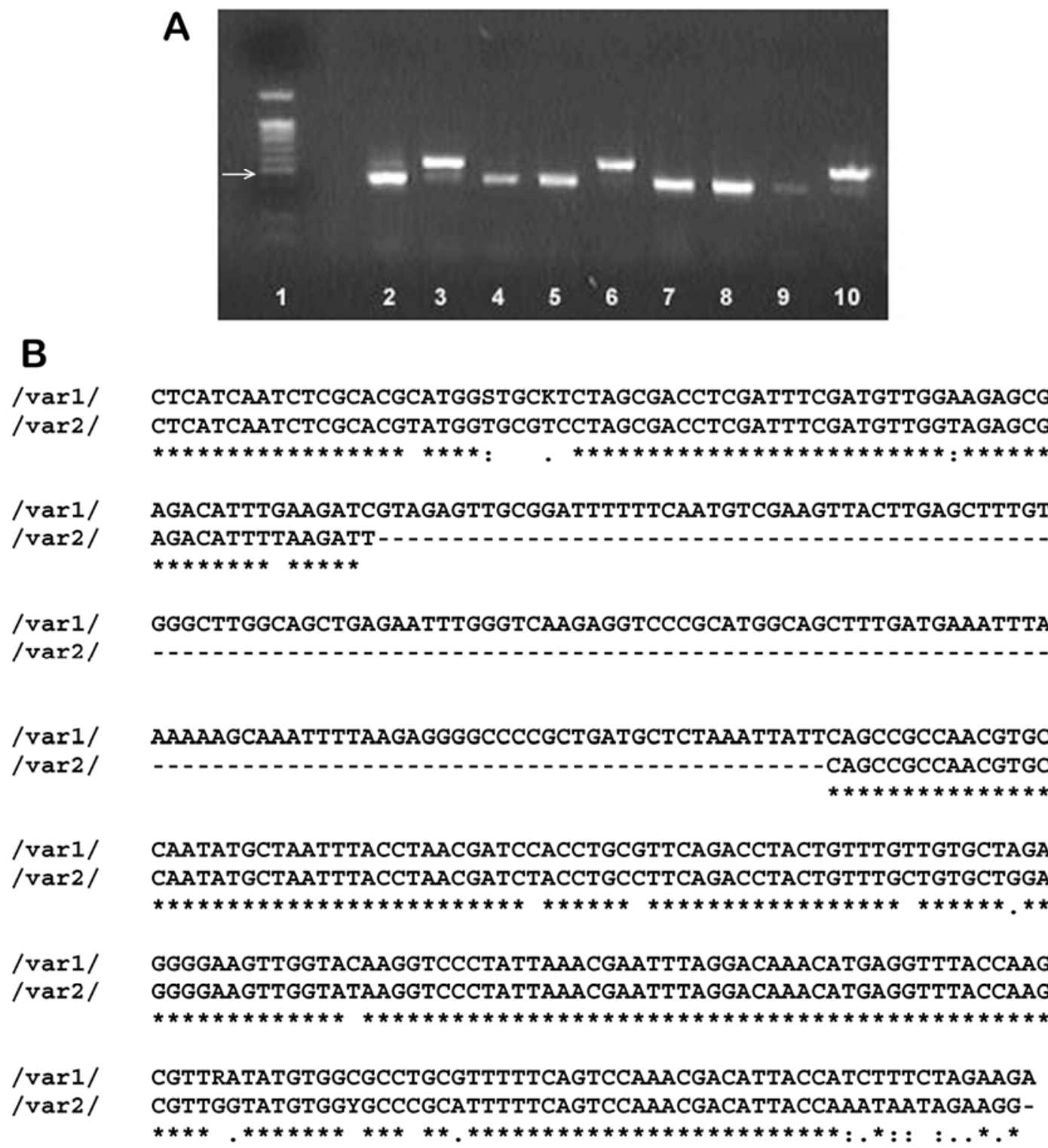

Fig. 5. Polymorphism in the right part of the Lv cellular transfer DNA fragments near the integration site. A, Separation of polymerase chain reaction (PCR) fragments on agarose gel. Lane 1, 100-bp + 1.5-kb ladder; arrow shows 500-bp fragment. Lanes 2 to 9, PCR fragments from different Linaria plants. B, Sequence alignment of two variants (var 1 corresponds to lanes 3, 6, and 10; var 2 corresponds to lanes 2, 4, 5, 7, 8, and 9). 
naphthalenacetic acetic and benzylaminopurine at $2 \mathrm{mg} / \mathrm{liter}$ (discussed in the following section). Expression of the reference gapdh gene was detected in all organs analyzed (values of threshold cycles: 23 to 25). However, mRNA corresponding to $\mathrm{Lv}$ rolB, Lv rolC, $\mathrm{Lv}$ ORF13, Lv ORF14, and Lv mis genes was not amplifiable from these tissues (data not shown). Thus, there is no evidence that the rol genes are expressed in $L$. vulgaris. However, we have not yet looked for transcripts of cTDNA under a wide variety of hormone treatments as well as at different stages of development.

\section{Estimation of $L$. vulgaris regeneration ability in vitro.}

Agrobacterium can transfer T-DNA into many plant species. However, in order to be fixed and transmitted, the T-DNA has to find its way to germ cells. The propensity for regeneration of whole plants from isolated organs in Nicotiana spp. (Clemente 2006; Li et al. 2003) and, possibly, also in L. vulgaris might contribute to this process. In this study, we tested the regeneration abilities of $L$. vulgaris in vitro. L. maroccana (which does not contain T-DNA-like sequences) was used as a control in these experiments.

Internode explants of the two L. vulgaris and L. maroccana species formed calli and shoots in vitro with different frequencies (Fig. 6) in different experiments. L. vulgaris exhibited a higher rate of regeneration. In general, calli on L. vulgaris explants were bigger and the frequency of shoot formation was higher than in L. maroccana. Calli and shoot formation on $L$. vulgaris explants was observed even in hormone-free medium, whereas L. maroccana explants were unable to form shoots in the medium lacking hormones.
Addition of naphthalenacetic acetic acid (NAA) to the culture media led to the formation of large calli and shoots on $L$. vulgaris explants and medium-sized calli on L. maroccana explants. No root formation was observed in these experiments. Benzylaminopurine (BA) induced formation of small calli on the explants of both species and shoot formation on $L$. vulgaris explants. Addition of NAA and BA to the culture media led to the formation of calli and shoots on the explants of both species.

\section{DISCUSSION}

Our results demonstrate that HGT of T-DNA from Agrobacterium to plants is not confined to Nicotiana spp. The data presented in this report indicate that HGT also took place in $L$. vulgaris, which belongs to the Scrophulariaceae family, representatives of which can be easily transformed by Agrobacterium (Aida et al. 2012; Cui et al. 2003; Georgiev et al. 2011; Koike et al. 2003; Pavlova et al. 2009; Sales et al. 2003).

It is interesting that the only examples of HGT shown thus far to occur naturally in plants involve $A$. rhizogenes and not A. tumefaciens. This might be explained by the relative ease of obtaining transformants from hairy roots induced by A. rhizogenes as opposed to tumors induced by A. tumefaciens (Tepfer 1984). The data on regeneration of $L$. vulgaris confirm that it can easily be regenerated in natural conditions from root fragments without hormone treatment. We have shown that the integration of Lv cT-DNA occurs at a site similar to the centromeric region of Arabidopsis thaliana, and a retrotransposon of Vicia spp. This site is most likely silent in vegetative tissues.
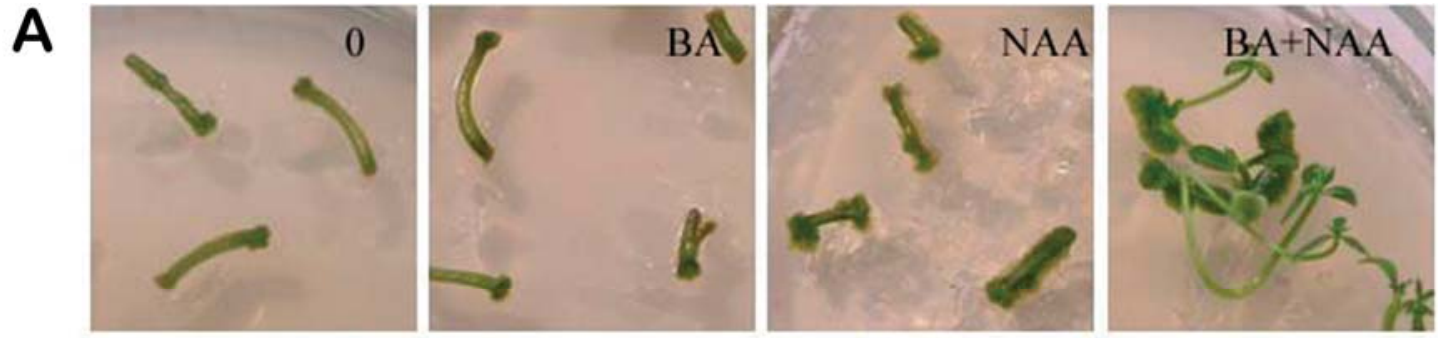

L.m.
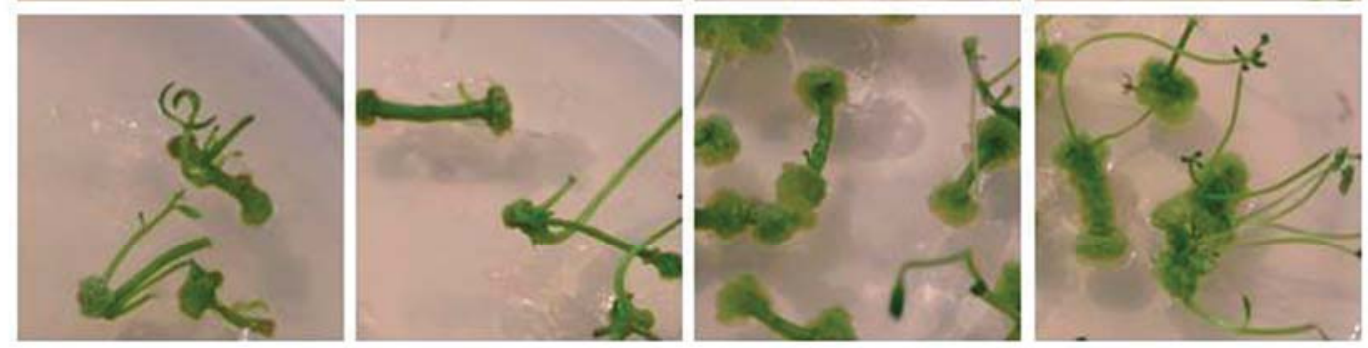

L.v.

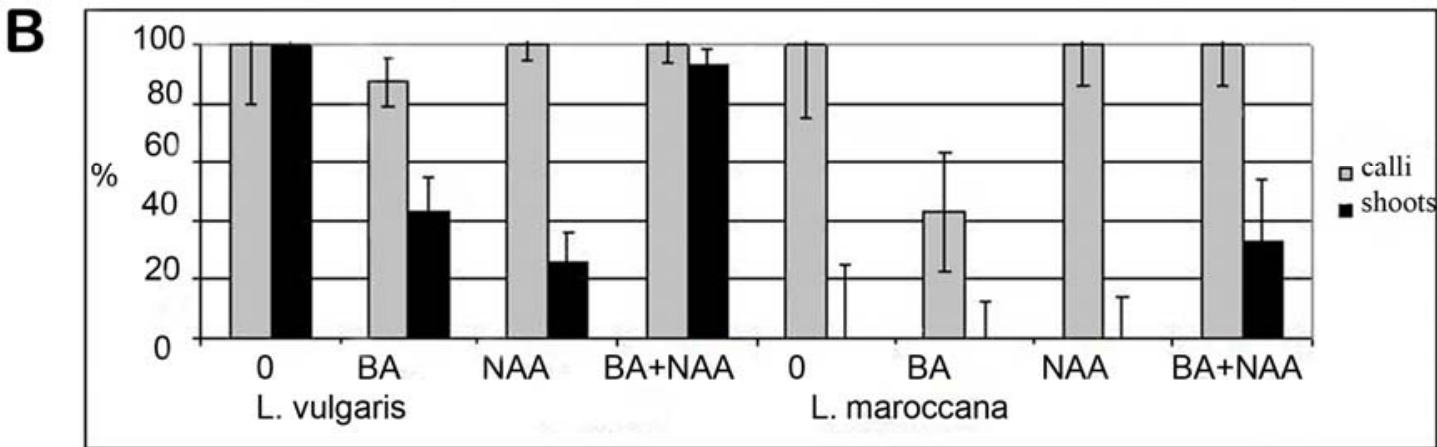

Fig. 6. Characteristics of the regeneration processes of Linaria vulgaris and L. maroccana in vitro. A, Photos of explants of the two Linaria spp. on different cultural media: $0=$ Murashige and Skoog (MS) media without hormones, benzylaminopurine (BA) = MS media with BA at $2 \mathrm{mg} / \mathrm{liter}$, naphthalenacetic acetic acid $(\mathrm{NAA})=\mathrm{MS}$ media with NAA at $2 \mathrm{mg} / \mathrm{liter}$, and BA+NAA = MS media with BA at $2 \mathrm{mg} / \mathrm{liter}$ and NAA at $2 \mathrm{mg} / \mathrm{liter}$. B, Percentage of different morphological reactions of internode explants of Linaria spp. on different cultural media. 
However, the high regeneration ability and the high cytokinin status of $L$. vulgaris are similar to the high regeneration ability of Nicotiana spp. containing cT-DNA-like sequences. T-DNA may have been retained in the genomes of both these genera because they are highly regenerative. This property in $L$. vulgaris may contribute to its vegetative and invasive habit (Lehnhoff 2008). Further experimentation with recombinant hybrids or mutant varieties should provide insight into the contributions, if any, of the cT-DNA of $L$. vulgaris.

The absence of T-DNA homologs in the majority of plant species analyzed leads us to conclude that HGT from Agrobacterium is a rare event in the evolution of plants. However, finding T-DNA-like sequences in a plant species other than Nicotiana indicates that HGT from Agrobacterium to plants is more widespread than previously thought. The existence of several independent acts of such transformation and the maintenance of the T-DNA during the evolution process suggests that TDNA-like sequences may confer some ecological advantages on the transformed plants.

Suzuki and associates (2002) discussed two possible functions of cT-DNA: increasing root mass leading to tolerance of dry conditions, and changing the biological environment, in particular, of the soil microflora such as the root-associated bacterial population. However, no phenotype of the hairy root syndrome is exhibited in Nicotiana and L. vulgaris plants. Moreover, L. vulgaris explants in vitro demonstrate a shooty phenotype. Our tissue culture data can better be interpreted in terms of the high regeneration ability and the high cytokinin status of L. vulgaris. This feature of L. vulgaris is similar, in part, to the high regeneration ability of Nicotiana spp. containing T-DNA-like sequences. T-DNA may have been retained in the genomes in both genera because they are highly regenerative. On the other hand, there is a big difference between these two examples of plants that contain Agrobacterium oncogenes: Nicotiana spp. demonstrate root formation whereas $L$. vulgaris exhibits shoot formation.

It is interesting to note that the rolC homolog is the most conserved gene among the T-DNA genes in Nicotiana spp. (Intrieri and Buiatti 2001; Mohajjel-Shoja et al. 2011). In some of the Nicotiana varieties, only rolC encodes a functional product (Mohajjel-Shoja et al. 2011). The same trend was observed in our study for $L$. vulgaris T-DNA-like sequences.

The function of rolC is poorly understood. One of the functions suggested for the product of rolC is to release cytokinins from conjugates (Estruch et al. 1991). Other reports show involvement of the RolC protein in such processes as sucrose metabolism or transport (Mohajjel-Shoja et al. 2011; Nilsson and Olsson 1997). RolC has also been hypothesized to induce somatic embryogenesis in plants (Gorpenchenko et al. 2006). This observation is consistent with a cytokinin function of the gene.
Sequencing of the mis homolog indicates that the origin of the Lv T-DNA is likely the mikimopine-type pRi, similar to the one that transformed some Nicotiana spp. This similarity may not be coincidental and may be connected somehow with plant-bacterium interactions. If opine synthesis became beneficial for some plants (even at a low level, or at a certain stage and in a specific tissue), then we can speculate about the first steps of appearance of beneficial plant-microbe interactions. Plants containing cT-DNA could potentially maintain bacteria of certain species in their rhizosphere due to the exudation of opines in the root zone. High numbers of possibly beneficial bacteria around the root might affect the root microbiome and have nutritional or defensive properties.

\section{MATERIALS AND METHODS}

\section{Biological materials.}

The vegetative material of all experimental plant species other than Linaria was collected in the St. Petersburg region, Russia. L. vulgaris plants were collected in different regions of Russia. Plant species were determined according to the criteria of Gubanov and associates (2003, 2004). Leaves or shoots were collected from plants growing in different ecosystems in the St. Petersburg region of Russia. These plant species are common for this region and belong to different families of Dicotyledones.

$N$. glauca plants were used as a positive control. Seed were supplied by the Research Institute of Tobacco Makhorka and Tobacco Products, Krasnodar, Russia. Wild-type strain 8196 of Agrobacterium rhizogenes (provided by T. Schmulling, Free University of Berlin) and wild-type strain C58 of A. tumefaciens (Wood et al. 2001) were used as positive controls.

\section{DNA and RNA isolation.}

Plant DNA was isolated by a method described by Dellaporta and associates (1983). Agrobacterium DNA was isolated as described by Sambrook and Russell (2001). RNA was isolated using the TRI Reagent LS (Sigma, St. Louis), according to the manufacturer's instructions.

\section{PCR.}

Type $i$. Degenerate Taq Man real-time PCR was done with 22- to 24-mer primers to conserved regions of four oncogenes of $A$. rhizogenes (re-rolCL: gtcgactgccracgatgatgc; re-rolCR: ggcgaagtargcgctccggata; re-rolBL: atgcagaaagtgctggaggaa; rerolBR:gtgcggccaagcaaggttgtg; re-ORF13L: ctttacctccmwggcc gtggc; re-ORF13R: ccagtgagacatttgtctgat; re-ORF14L: gstkga ggcggmgctackdgacta; re-ORF14R: atcarcaatggagttgagtttctc) and two oncogenes of $A$. tumefaciens (re-tmsL: aatggtcgataagg ctgatga; re-tmsR: gaaagcgaccrtcggccagcct; re-iptL: tcatcgcagc caagcaagctca; re-iptR: gttggcgaataatatgccaacga); and the fol-

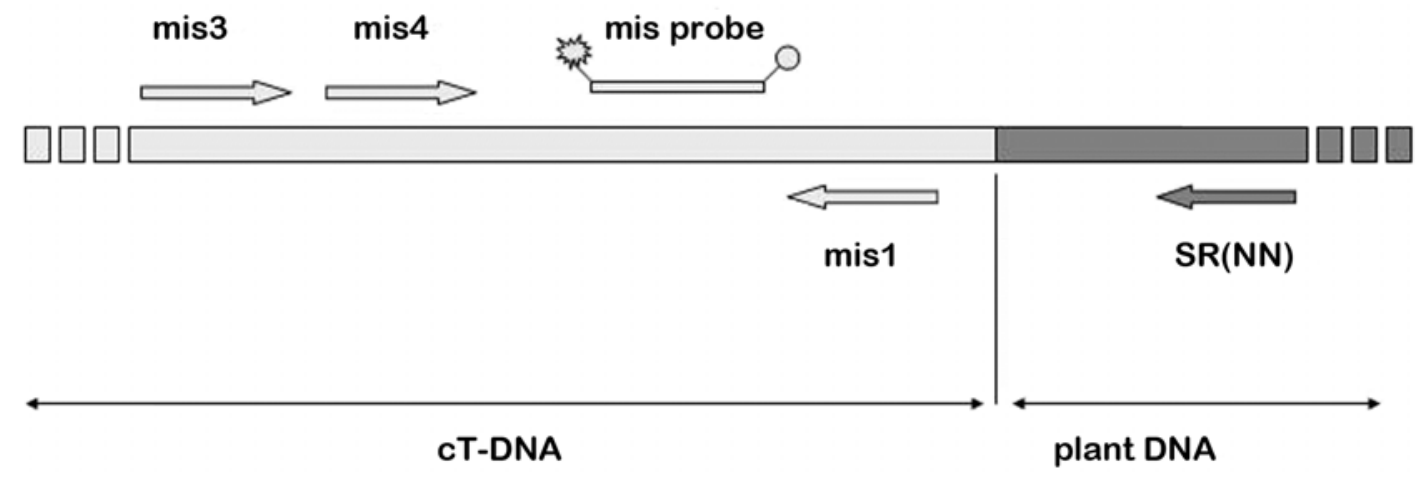

Fig. 7. Location of primers and probes for real-time thermal asymmetrical interlaced polymerase chain reaction. 
lowing degenerate probes to the conserved regions of the corresponding genes: rolB_probe: R6G-atcgtbgtcgcagcacggectc cattcca-BHQ1; rolC_probe: Cy5-tcmtcaccaatcttccgecgtaccagBHQ2; ORF13_probe: Rox-aggaacgacgcasgmtaacagntccccatcBHQ2; ORF14_probe: FAM-ctcgatcarwctgtgackgtcgacaagcBHQ1; and tms_probe: Rox-tgcaagctaaccagcgytgcactcgBHQ2; iIpt_probe: R6G-ccatgcacytgagcaacgagatagat-BHQ2.

Type ii. RT real-time PCR was done to estimate oncogene expression. RT was done using the kit "Synthesis of the first chain of the cDNA (oligo(dT) $)_{15}$ )" and following directions in the manual supplied by the manufacturer (Sileks M, St. Petersburg, Russia); cDNA was then used for real-time PCR with primers and probes to rolB, rolC, ORF13, and ORF14 (discussed above). The gene gapdh coding for glyceraldehyde-3phosphate dehydrogenase was used as a reference gene: Gapdh-F: 5'-ACT GGT GTC TTC ACT GAC AAG G, GapdhR: 5'-T GAC ACC CAC AAC AAA CAT CGG, Probe Gapdh: 5'-Cy5-ACA AGG CTG CTG CTC ACT TGA AGG-BHQ3. All primers and probes were synthesized by Beagle Co. Ltd. and Syntol Company, (Moscow).

Type iii. Real-time-TAIL-PCR. Primers and probes to the mis gene (mis3: ctcaacagttgcaagagtgtggtc; mis4: tgctctcgtttgtatcgccg tatg; mis Probe: FAMcggcagatgagagtaaacaagatccaccacBHQ1) were used with eight semi-specific primers (Supplementary Table S2). The first round of the reaction was done with primer mis3, probe, and one of the semi-specific primers. The second round was done only for those combinations in which fluorescence was detected in the first round. This PCR was done on the template obtained in the first round, using the primer mis4, probe, and the corresponding semi-specific primer (Fig. 7).

The reaction volume was $30 \mu \mathrm{l}$ and the reaction contained $100 \mathrm{ng}$ of DNA, $1.5 \mathrm{U}$ of Taq polymerase (Sileks M) and the enzyme buffer provided by this company, $10 \mathrm{nM}$ each dNTP, $10 \mathrm{pM}$ each primer, and $5 \mathrm{pM}$ probe (depending on the number of degenerate positions and the type of fluorescent dye).

PCR was carried out according to the following program: 5 min at $93^{\circ} \mathrm{C} ; 40$ cycles of $15 \mathrm{~s}$ at $93^{\circ} \mathrm{C}, 60 \mathrm{~s}$ at $\mathrm{X}^{\circ} \mathrm{C}$, and $60 \mathrm{~s}$ at $72^{\circ} \mathrm{C}$; followed by $15 \mathrm{~s}$ at $25^{\circ} \mathrm{C}$, using an ANA 16 gene cycler (Institute for Analytical Instrumentation of Russian Academy of Science, St. Petersburg, Russia). For real-time PCR (types i and ii), $X=50$ and for type iii, $X=45$.

Classical variants of PCR were done with primers shown in Supplementary Table S3, using a Tercyc gene cycler from DNA Technology, Russia. $50 \mu 1$ of reaction mixture contained $100 \mathrm{ng}$ of DNA, $10 \mathrm{pM}$ of primer, $2.5 \mathrm{U}$ of Taq polymerase (Sileks M), the enzyme buffer provided by this company, and $200 \mu \mathrm{M}$ of each dNTP. PCR was carried out according to the following program: $5 \mathrm{~min}$ at $93^{\circ} \mathrm{C} ; 33$ cycles of $17 \mathrm{~s}$ at $93^{\circ} \mathrm{C}$, $40 \mathrm{~s}$ at $\mathrm{X}^{\circ} \mathrm{C}$, and $40 \mathrm{~s}$ at $72^{\circ} \mathrm{C}$; followed by $5 \mathrm{~min}$ at $72^{\circ} \mathrm{C}$, when $\mathrm{X}$ was annealing temperature, and it depended on the primer used.

PCR with the LONG PCR enzyme Mix (Fermentas) was carried out according to the instructions for the kit. Two pairs of primers were used for this experiment: LF: ACCGATCGGT CACTTGCTGCGATCTG and LR: GGTAAATTAGCATATT GGCACGTTGGCGAC; PF: CTCTGATGTCACCGAATTTG CTCTCCATAAC and PR: GGTAATGTCGTTTGGACTGAA AAATGCGG.

Fragments were separated on a $1 \%$ agarose gel in $1 \times$ Trisacetate-EDTA buffer. A 100-bp + 1.5-kb ladder (Sibenzyme, Novosibirsk, Russia) served as the molecular weight marker. Gel images were obtained using a gel documentation system (Sileks M).

\section{Digital PCR.}

Digital PCR was done in 64 tubes with the reaction volume of $20 \mu \mathrm{l}$ and contained $1 \mu \mathrm{l}$ of highly dissolved DNA, $1.5 \mathrm{U}$ of
Taq polymerase (Sileks M) and the enzyme buffer provided by this company, $10 \mathrm{nM}$ each dNTP, $10 \mathrm{pM}$ each primer, and 5 pM probe (Gapdh-F: 5'-ACT GGT GTC TTC ACT GAC AAG G, Gapdh-R: 5'-T GAC ACC CAC AAC AAA CAT CGG, Probe Gapdh: 5'-Cy5-ACA AGG CTG CTG CTC ACT TGA AGG-BHQ3, ORF2UF GCGAATACGTTAGCTCCAAA, ORF2UPr FAM-CCAACCCAGAAAGCAATCCCGTTTATTBHQ1, ORF2UR GATATGCTGACTGTCGTCGG).

PCR was carried out according to the following program: 5 min at $93^{\circ} \mathrm{C} ; 40$ cycles of $15 \mathrm{~s}$ at $93^{\circ} \mathrm{C}, 40 \mathrm{~s}$ at $50^{\circ} \mathrm{C}$, and $40 \mathrm{~s}$ at $72^{\circ} \mathrm{C}$; followed by $15 \mathrm{~s}$ at $25^{\circ} \mathrm{C}$, using an ANA16 gene cycler. Calculation of the amount of molecules was done by the standard curve method for absolute quantification.

\section{Cloning and sequencing of DNA fragments.}

Specific PCR products were isolated from the gel, filtered through glass wool (Sigma), ethanol precipitated, dissolved in water, cloned using the InsT/Aclone PCR product cloning kit or the Clone Jet PCR cloning kit (Fermentas), and then transformed into Escherichia coli $\mathrm{DH} 5 \alpha$ cells by electroporation using the Gene Pulser Xcell Electroporation System (Bio-Rad, Munich).

The sequencing of rolB-, rolC-, ORF13-, ORF14-, and mislike sequences was done according to the chain-termination or Sanger method in a cyclic sequencing reaction (Sambrook and Russell 2001) from Cy5-labeled M13 primer (Amersham Pharmacia Biotech, Piscataway, NJ, U.S.A.). Polyacrylamide gel electrophoresis separation of the sequencing reaction products and visualization of the data were done using ALF express II DNA sequencer (Amersham Pharmacia Biotech) according to the procedure recommended by the company for this equipment.

Chromosome walking was done to completely describe the T-DNA in L. vulgaris. A series of PCR amplifications was done with the following primers: the reverse primer was highly homologous to the known part of Lv c-TDNA, and the forward primers were designed to correspond to the 500- to 1,000-bp upstream parts of the Agrobacterium T-DNA sequence. Successful amplification products were sequenced, and new reverse primers were designed.

Sequencing of large DNA fragments was done with the DYEnamic ET dye terminator kit according to the instructions for the kit. Separation of the sequencing reaction products and visualization of the data were done using the MegaBACE sequencer (General Electric, Piscataway, NJ, U.S.A.).

The obtained sequences were compared with GenBank databases on the Internet. Multiple sequence alignments were made using Clustal W available at the Kyoto University Bioinformatics Center website. Phylogenetic trees were constructed using the neighbor-joining method (Saitou and Nei 1987).

\section{Tissue culture experiments.}

To obtain aseptic plants, seed were treated with $10 \% \mathrm{H}_{2} \mathrm{O}_{2}$ and plated on Murashige and Skoog (MS) cultural medium (Murashige and Skoog 1962) under conditions of a laminar chamber. Internode explants from 2-month-old plants were used to estimate regeneration ability. They were plated on MS medium without phytohormones, MS medium with NAA at 2 $\mathrm{mg} /$ liter (Sigma) or BA at $2 \mathrm{mg} /$ liter (Sigma), or both. Morphogenetic responses were estimated 1.5 months after explanation.

\section{ACKNOWLEDGMENTS}

The research described in this publication was made possible, in part, by award number T-012-0 of the United States Civilian Research and Development Foundation for the Independent States of the Former Soviet Union (CRDF), award number 08-04-01005-a of Russian Foundation for Basic Research, and Grant of President of RF, MK-5352.2006.4. We thank 
W. Deng (University of British Columbia, Canada), F. White, (Kansas State University), and I. A. Tikhonovich (All-Russia Research Institute for Agricultural Microbiology, Russia) for discussions of the data and the article; and N. Vidhya (School of Biology Georgia Institute of Technology) for proofreading the manuscript.

\section{LITERATURE CITED}

Acuna, R., Padilla, B. E., Florez-Ramos, C. P., Rubio, J. D., Herrera, J. C., Benavides, P., Lee S.-J., Yeats, T. H., Egan, A. N., Doyle, J. J., and Rose, J. K. C. 2012. Adaptive horizontal transfer of a bacterial gene to an invasive insect pest of coffee. Proc. Natl. Acad. Sci. U.S.A. 109:4197-4202.

Aida, R. 2012. A protocol for transformation of Torenia. Methods Mol. Biol. 847:267-274.

Aoki, S., Kawaoka, A., Sekine, M., Ichikawa, T., Fujita, T., Shinmyo, A., and Syono, K. 1994. Sequence of the cellular T-DNA in the untransformed genome of Nicotiana glauca that is homologous to ORFs 13 and 14 of the Ri plasmid and analysis of its expression in genetic tumors of $N$. glauca $\times N$. langsdorffii. Mol. Gen. Genet. 243:706-710.

Blair, P. L., Witney, A., Haynes, J. D., Moch, J. K., Carucci, D. J., and Adams, J. H. 2002. Transcripts of developmentally regulated Plasmodium falciparum genes quantified by real-time RT-PCR. Nucleic Acids Res. 30:2224-2231.

Clemente T. 2006. Nicotiana (Nicotiana tobaccum, Nicotiana benthamiana). Methods Mol. Biol. 343:143-54

Cui, M. L., Handa, T., and Ezura, H. 2003. An improved protocol for Agrobacterium-mediated transformation of Antirrhinum majus L. Mol. Genet. Genomics. 270:296-302.

Dellaporta, S. L., Wood, J., and Hicks, J. B. 1983. Plant DNA mini preparation. Molecular biology of plants. A laboratory course manual. Plant Mol. Biol. Rep. 1:19-21.

Dong, F., Wilson, K. G., and Makaroff, C. A. 1998. Analysis of the four cox2 genes found in turnip (Brassica campestris, Brassicaceae) mitochondria. Am. J. Bot. 85:153-161.

Estruch, J. J, Chriqui D., Grossmann, K., Schell J., and Spena, A. 1991. The plant oncogene rolC is responsible for the release of cytokinins from glucoside conjugates. EMBO (Eur. Mol. Biol. Organ.) J. 10:28892895.

Furner, I. J., Huffman, G. A., Amasino, R. M., Garfinkel, D. J., Gordon, M. P., and Nester, E. W. 1986. An Agrobacterium transformation in the evolution of the genus Nicotiana. Nature 329:422-427.

Garcia-Vallve, S., Romeu, A., and Palau, J. 2000. Horizontal gene transfer of glycosyl hydrolases of the rumen fungi. Mol. Biol. Evol. 17:352-361.

Georgiev, M. I., Ludwig-Müller, J., Alipieva, K., and Lippert, A. 2011. Sonication-assisted Agrobacterium rhizogenes-mediated transformation of Verbascum xanthophoeniceum Griseb. for bioactive metabolite accumulation. Plant Cell Rep. 30:859-866.

Ghatnekar L., Jaarola, M., and Bengtsson, B. O. 2006. The introgression of a functional nuclear gene from Poa to Festuca ovina. Proc. Biol. Sci. 273:395-399.

Gogarten, J. P., Doolittle, W. F., and Lawrence, J. G. 2002. Prokaryotic evolution in light of gene transfer. Mol. Biol. Evol. 19:2226-2238.

Gorpenchenko, T. Y., Kiselev, K. V., Bulgakov, V. P., Tchernoded, G. K, . Bragina, E. A., Khodakovskaya, M. V., Koren, O. G., Batygina, T. B., and Zhuravlev, Yu. N. 2006 The Agrobacterium rhizogenes rolC-geneinduced somatic embryogenesis and shoot organogenesis in Panax ginseng transformed calluses. Planta 223:457-467.

Gubanov, I. A., Kiseleva, K. V., Novikov, V. S., and Tikhomirov, V. N. 2003. Illustrated Key to Plants of Middle Russia. Vol. 2. KMC, the Institute for Technological Research, Moscow.

Gubanov, I. A., Kiseleva, K. V., Novikov, V. S., and Tikhomirov, V. N. 2004. Illustrated Key to Plants of Middle Russia. Vol. 3. KMC, the Institute for Technological Research, Moscow.

Ichikawa, T., Ozeki, Y., and Syono, K. 1990. Evidence for the expression of the rol genes of Nicotiana glauca in genetic tumors of N. glauca $\times N$. langsdorffii. Mol. Gen. Genet. 220:177-180.

Intrieri, M. C., and Buiatti, M. 2001. The horizontal transfer of Agrobacterium rhizogenes genes and evolution of the genus Nicotiana. Mol. Phylogenet. Evol. 20:100-110.

Jenkins, C., Samudrala, R., Anderson I., Hedlund, B. P., Petroni, G., Michailova, N., Pinel, N., Overbeek, R., Rosati, G., and Staley, J. T. 2002. Genes for the cytoskeletal protein tubulin in the bacterial genus Prosthecobacter. Proc. Natl. Acad. Sci. U.S.A. 99:17049-17054.

Koike, Y., Hoshino, Y., Mii, M., and Nakano, M. 2003. Horticultural characterization of Angelonia salicariifolia plants transformed with wildtype strains of Agrobacterium rhizogenes. Plant Cell Rep. 21:981-987.

Kondo, N., Nikoh, N., Ijichi, N., Shimada, M., and Fukatsu, T. 2002. Genome fragment of Wolbachia endosymbiont transferred to X chromo- some of host insect. Proc. Natl. Acad. Sci. U.S.A. 99 14280-14285.

Koonin, E. V., Makarova, K. S., and Aravind, L. 2001. Horizontal gene transfer in prokaryotes: Quantification and classification. Annu. Rev. Microbiol. 55:709-742.

Lehnhoff, E. A. 2008. Invasiveness of yellow toadflax (Linaria vulgaris) resulting from disturbance and environmental conditions. A dissertation submitted in partial fulfillment of the requirements for the degree of Doctor of Philosophy in Ecology and Environmental Sciences, Montana State University, Bozeman, MT, U.S.A.

Li, B., Huang, W., and Bass, T. 2003. Shoot production per responsive leaf explant increases exponentially with explant organogenic potential in Nicotiana species. Plant Cell Rep. 22:231-238.

Livak, K. J., Flood, S. J., Marmaro, J., Giusti, W., and Deetz, K. 1995. Oligonucleotides with fluorescent dyes at opposite ends provide a quenched probe system useful for detecting PCR product and nucleic acid hybridization. PCR Methods Appl. 4:357-362.

Matveeva, T. V., Lutova, L. A., Wood, D., and Nester, E. W. 2003. Search for sequences homologous to Agrobacterium T-DNA in different plant genomes. Biol. Plant-Microbe Interact. 4:526-529.

Matveeva, T. V., Lutova, L. A., and Bogomaz, D. I. 2006. Search for TDNA-like sequences in plant genomes, using real-time PCR with degenerate primers and probe. Pages 101-104 in: Biotechnology in the Agriculture and Food Industry. Nova Science Publishers, New York.

Meyer, A. D., Ichikawa, T., and Meins, F. 1995. Horizontal gene transfer: Regulated expression of a tobacco homologue of the Agrobacterium rhizogenes rolC gene. Mol. Gen. Genet. 249:265-273.

Mohajjel-Shoja, H., Clément, B., Perot, J., Alioua, M., and Otten, L. 2011. Biological activity of the Agrobacterium rhizogenes-derived trolC gene of Nicotiana tabacum and its functional relation to other plast genes. Mol. Plant-Microbe Interact. 24:44-53.

Murashige, T., and Skoog, F. 1962. A revised medium for rapid growth and bio-assays with tobacco tissue cultures. Physiol. Plant. 15:473-497.

Nagata, N., Kosono, S., Sekine, M., Shinmyo, A., and Syono, K. 1995. The regulatory functions of the rolB and rolC genes of Agrobacterium rhizogenes are conserved in the homologous genes $(\mathrm{Ng} \mathrm{rol})$ of Nicotiana glauca in tobacco genetic tumors. Plant Cell. Physiol. 36:10031012.

Nilsson, O., and Olsson, O. 1997. Getting to the root: The role of the Agrobacterium rhizogenes rol genes in the formation of hairy roots. Physiol. Plant. 100:463-473.

Otten, L., Canaday, J., Gerard, J. C., Fournier, P., Crouzet, P., and Paulus, F. 1992. Evolution of agrobacteria and their Ti plasmids. Mol. PlantMicrobe Interact. 5:279-87.

Otten, L., Burr, T., and Szegedi, E. 2007. Agrobacterium: A disease-causing bacterium. Pages 1-46 in: Chapter 1. Agrobacterium: From Biology to Biotechnology. T. Tzifra and V. Citovsky, eds. Springer, New York.

Pavlova, O. A., Matveeva, T. V., and Lutova, L. A.2009. Characteristics of the ability of Linaria plants to Agrobacterium mediated transformation. Page 553 in: Abstr. Fifth Cong. Vavilov Soc. Genet. Breed. (VOGiS), Part 1, Moscow.

Richards, T. A., Dacks, J. B., Campbell, S. A., Blanchard, J. L., Foster, P. G., McLeod, R., and Roberts, C. W. 2006. Evolutionary origins of the eukaryotic shikimate pathway: Gene fusions, horizontal gene transfer, and endosymbiotic replacements. Eukaryot. Cell. 5:1517-1531.

Richardson, A. O., and Palmer, J. D. 2007. Horizontal gene transfer in plants. J. Exp. Bot. 58:1-9.

Rogers, M. B., Patron, N. J., and Keeling, P. J. 2007. Horizontal transfer of a eukaryotic plastid-targeted protein gene to cyanobacteria. BMC Biol. 5:26.

Rosewich, U. L., and Kistler, H. C. 2000. Role of horizontal gene transfer in the evolution of fungi. Annu. Rev. Phytopathol. 38:325-363.

Saitou, N., and Nei, M. 1987. The neighbor-joining method: A new method for reconstructing phylogenetic trees. Mol. Biol. Evol. 4:406-425.

Sales, E., Segura, J., and Arrillaga, I. 2003 Agrobacterium tumefaciensmediated genetic transformation of the cardenolide-producing plant Digitalis minor L. Planta Med. 69:143-147.

Salvi, S., D'Orso, F., and Morelli, G. 2008. Detection and quantification of genetically modified organisms using very short, locked nucleic acid TaqMan probes. J. Agric. Food Chem. 56:4320-4327.

Sambrook, J., and Russell, D. W. 2001. Molecular Cloning: A Laboratory Manual, 3rd ed. Cold Spring Harbor Laboratory Press, Cold Spring Harbor, NY, U.S.A

Schlieper, D., Oliva, M. A., Andreu, J. M., and Lowe, J. 2005. Structure of bacterial tubulin BtubA/B: Evidence for horizontal gene transfer. Proc. Natl. Acad. Sci. U.S.A. 102:9170-9175.

Screen, S. E., and St. Leger, R. J. 2000. Cloning, expression and substrate specificity of a fungal chymotrypsin - evidence for lateral gene transfer from an actinomycete bacterium. J. Biol. Chem. 275 6689-6694.

Spano, L., Pomponi, M., Costantino, P., vanSlogteren, G. M. S., and Tempé, J. 1982. Identification of T-DNA in the root-inducing plasmid 
of the agropine type Agrobacterium rhizogenes 1855. Plant. Mol. Biol. 1:291-304.

Suzuki, K., Yamashita, I., and Tanaka, N. 2002. Tobacco plants were transformed by Agrobacterium rhizogenes infection during their evolution. Plant J. 32:775-787.

Sykes, P. J., Neoh, S. H., Brisco, M. J., Hughes, E., Condon, J., and Morley, A. A. 1992. Quantitation of targets for PCR by use of limiting dilution. Biotechniques 13:444-449.

Tepfer, D. 1984. Transformation of several species of higher plants by Agrobacterium rhizogenes: Sexual transmission of the transformed genotype and phenotype. Cell 37:959-67.

Tzfira, T, and Citovsky, V. 2006. Agrobacterium-mediated genetic transformation of plants: Biology and biotechnology. Curr. Opin. Biotechnol. 17:147-154.

Vain, P. 2007. Thirty years of plant transformation technology development Plant Biotechnol. J. 5:221-229.

Vallenback, P., Jaarola, M., Ghatnekar, L., and Bengtsson, B. O. 2008. Origin and timing of the horizontal transfer of a PgiC gene from Poa to Festuca ovina. Mol. Phylogenet. Evol. 46:890-896.

Vallenback, P., Bengtsson, B. O., and Ghatnekar, L. 2010. Geographic and molecular variation in a natural plant transgene. Genetica 138:355-362.

Veena, H.-J., Doerge, R. W., and Gelvin, S. B. 2003. Transfer of T-DNA and Vir proteins to plant cells by Agrobacterium tumefaciens induces expression of host genes involved in mediating transformation and suppresses host defense gene expression. Plant J. 5:219-236.

Veronico, P., Jones, J., Di Vito, M., and De Giorgi, C. 2001. Horizontal transfer of a bacterial gene involved in polyglutamate biosynthesis to the plant-parasitic nematode Meloidogyne artiellia. FEBS (Fed. Eur. Biochem. Soc.) Lett. 508:470-474.

White, F. F., Ghidossi, G., Gordon, M. P., and Nester, E. W. 1982. Tumor induction by Agrobacterium rhizogenes involves the transfer of plasmid DNA to the plant genome. Proc. Natl. Acad. Sci. U.S.A. 79:31933319

White, F. F., Garfinkel, D. J., Huffman, G. A., Gordon, M. P., and Nester, E. W. 1983. Sequence homologous to Agrobacterium rhizogenes TDNA in the genomes of uninfected plants. Nature 301:348-350.

Wood, D. W., Setubal, J. C., Kaul, R., Monks, D. E, Kitajima J. P., Okura, V. K., Zhou Y., Chen, L., Wood, G. E., Almeida, N. F., Jr., Woo, L., Chen, Y., Paulsen, I. T., Eisen, J. A., Karp, P. D., Bovee, D., Sr., Chapman, P., Clendenning, J., Deatherage, G., Gillet, W., Grant, C., Kutyavin, T., Levy, R., Li, M.-J., McClelland, R., Palmieri, A., Raymond, C., Rouse, G., Saenphimmachak, C., Wu, Z., Romero, P., Gordon, D., Zhang, S., Yoo, H., Tao, Y., Biddle, P., Jung, M., Krespan, W., Perry, M., GordonKamm, B., Liao, L., Kim, S., Hendrick, C., Zhao, Z.-Y., Dolan, M., Chumley, F., Tingey, S. C., Tomb, J.-F., Gordon, M. P., Olson, M. V., and Nester, E. W. 2001. The Genome of the Natural Genetic Engineer Agrobacterium tumefaciens C58. Science 294:2317-2323.

\section{AUTHOR-RECOMMENDED INTERNET RESOURCE}

Gene Quantification website: digital-pcr.gene-quantification.info 